\title{
An Ethnographic Narrative of Relational Leadership
}

\author{
Brigitte Smit \\ Department of Educational Leadership and Management, College of Education, \\ University of South Africa \\ Fax: +27-12-9912569 E-mail: smitb@unisa.ac.za
}

KEYWORDS Feminist Research. Female Leadership. Storied Field Texts

\begin{abstract}
Educational leadership is an important subject in the literature, which is mostly investigated from a male tradition. Little research is conducted on a feminine approach, such as relational leadership in educational leadership studies. This paper offers an ethnographical and narrative perspective of relational leadership, observing and speaking to a female school principal. Through an inductive qualitative data analysis, working observational and storied field texts into research texts, this inquiry traced the qualities that characterise a feminine approach to leadership in contrast to the more traditional approach. Narratives 'from the ground' together with ethnographic observational field texts redefine leadership, and bring about a new language about leadership, and one that disrupts the male dominated discourse of leadership. Discerning the feminist attributes evident from the field texts speak to the explanatory power of attributes in relational leadership, such as care, collaboration, vision, intuition and courage.
\end{abstract}

\section{INTRODUCTION}

This paper illustrates relational leadership in a disadvantaged school in South Africa. It is an interpretive and qualitative inquiry that seeks to understand relational leadership (Cathcart 2014; Wang et al. 2014; Fairhurst and Uhl Bien 2012), in order to describe educational challenges of school leadership in disadvantaged schools. In the inquiry the researcher worked qualitatively as non-participant observer in the school over a period of three years. The research design was an ethnographic narrative, collecting data from guided conversations (Hollingsworth 1992) and observations.

To date little research is conducted on a feminine approach, such a relational leadership in educational leadership studies. Most research focuses on the traditional approach of educational leadership. This paper offers a new of leadership approach, namely relational leadership, specifically in disadvantaged school contexts. As preface of this inquiry, the researcher takes the prompt from Grogan and Shakeshaft (2011: 6) who claim that "much of the research about leadership has been critiqued for the absence of women in educational leadership studies. Studies, conducted only with men, have been generalised to all leaders without identifying them as single gender implies that research on educational leadership presents a biased interpretation, which leans strongly towards the views of men." That said, a great deal of empirical research in educational leadership is restricted by positivist research frameworks that neglect to offer a vibrant and multi-dimensional description of relational leadership from a feminist perspective in a context of disadvantaged schools (Young and Lopez 2005: 340). The empirical design employed in this inquiry offers an interpretive and qualitative approach for in-depth understandings of the multiple realities of relational leadership in a particular disadvantaged educational landscape. The inquiry also proposes an alternative theoretical perspective of a feminist relational leadership, which offers the potential to strengthen the knowledge base around female educational leadership. The research question that guides this inquiry is, what can relational leadership offer to enhance leadership practices in disadvantaged communities in the South African context? The aim is thus to explore and explain how relational leadership can enhance leadership practices in disadvantaged schools.

\section{Theoretical Framework}

An emerging trend in female leadership theories is the relational perspective and approach Cathcart (2014), Fairhurst and Uhl Bien (2012) and Uhl-Bien and Ospina (2012). Uhl-Bien (2006, 2007, 2011a, 2011b), who wrote extensively on this topic, explains that the term relational lead- 
ership is quite new, although the concept of relation-oriented behaviour is not so new in leadership studies (2006: 654). Carol Gilligan, in 1982, in her well known text, in a different voice, proposed, somewhat provocatively that females value relationships more than males. This resulted in further research on female approaches to leadership with documented relational aspects, evidenced in communication styles, teamwork, collaboration and community connection (Shakeshaft 2006: 506). Earlier writings on relational leadership (Regan and Brooks 1995) offer insights into how women transformed their understanding of school leadership. These women were insiders and resisted the traditional administrative behaviour as modelled by their male counterparts (Smit 2013). In their research, Regan and Brooks (1995) developed relational leadership as a theory based on empirical data sourced from eleven (11) women, who resisted socialisation into the prevailing male dominant culture (ibid: xi).These accounts of their practice were described as relational as opposed to controlling. Leadership as relational influence can be performed by anyone; it is not a person or a place or a thing, instead it is a verb: "leadership is the action of influence; it is relation, and it does not exist by itself' (Schmuck and Schmuck 1992 cited by Regan and Brooks 1995: xi). A new language that is relational is offered, including concepts such as care, vision, collaboration, courage and intuition, which are seen to be feminist attributes of leadership. While these concepts are not new in the vocabulary, they are given new conceptualizations for the practice of relational leadership (Smit 2013).

Attributes of relational leadership differ greatly from the traditional administrative language of control, hierarchy, authority and division of labour. Whilst relational and traditional language is at opposite ends, it does not mean that relational language is only meant for female school principals. Instead it is meant for all genders. What is enlightening is that the "increased presence of women administrators, as well as [the] emerging feminist scholarship in this field, is corollary to the widening acceptance of the idea of leadership as relational" (Regan and Brooks 1995: xi). The place of relational leadership in the framework varies because people have used the term in different ways. One definition posed is that relational leadership as "a process of rolebased reciprocal interrelating" between workers and managers to negotiate the work that is to be done. In contrast, Uhl-Bien (2006) defines relational leadership as "a social influence process through which emergent coordination (that is, evolving social order) and change (for example, new values, attitudes, approaches, behaviours, and ideologies) are constructed and produced." (2006: 655) The first definition implies that leadership exists in independent individuals who inter-relate across different hierarchical positions. The second locates leadership in a jointly constructed but disembodied process, not in individuals. Uhl-Bien (2006) proposes a Relational Leadership Theory as an approach that can encompass both individuated and connected perspectives by explaining both the emergence of leadership relationships (drawing on traditional individuated views that focus on the nature of the relationship, such as Leader-Member Exchange), and the relational dynamics of organizing, which includes various constructionist views of leadership.

Grogan and Shakeshaft (2011) explore the concept of relational leadership based on research conducted with female leaders in educational contexts. Grogan and Shakeshaft (2011) suggest that relational leadership is about being in relationships with others in a horizontal rather than a hierarchical sense (Grogan and Shakeshaft 2001: 6). Stated differently, relations produce power in a flattened organisational structure. "Leaders who develop coherence around shared values are likely to deepen the sense of community with an organization - a sense of being in relationship with others who are striving for the same goals" (Grogan and Shakeshaft 2001: 47). Achieving goals usually takes place with and through others; power is conceptualised differently emphasising that power of everyone should be expanded. Given the male dominance of power, women often would express their discomfort with power and deny their own power. What has changed is the language in use about power, from power with rather than power over (Grogan and Shakeshaft 2001: 7).This signals a relational approach of power in the work of female leaders. Power is conceptualised by women as something that is shared and therefore they seek to expand everyone's power (Grogan and Shakeshaft 2011). In fact, the term "relational" has been used to refer to quite distinct understandings of leadership, each with different ontological and epistemo- 
logical assumptions that result in quite distinct approaches to conducting research (Uhl-Bien and Ospina 2012). However, relational leadership does more than draw upon expertise and leadership from participants throughout the organization. It is a process of reciprocal interrelating through which the expertise held by different participants interpenetrates, creating a more holistic perspective that is integrative rather than additive. Relational leadership requires facilitating the interpenetration of expertise among others, which in turn requires the skills to build relationships among others, creating a safe space in which they can reciprocally interrelate with each other.

\section{RESEARCH DESIGN AND METHODOLOGY}

By way of introducing the qualitative research design and methodology for a leadership study, it is noted that leadership scholarship has largely been quantitative in orientation, grounded in the objectivist and positivist paradigm (Klenke 2008: 200-204, 321). However, narrative inquiry and ethnography as qualitative design types are slowly edging their way into leadership studies. Such qualitative inquiries offer "opportunities to explore leadership phenomena in significant depth, do so longitudinally, and answer 'why' questions about leadership as opposed to 'how' and 'what' type of questions as might be answered by quantitative research" (Klenke 2008: 5). For the purpose of this study, feminist qualitative research frames the design and methodology. This considers how race, class, gender, age and material circumstances, in multiple contexts which render the taken for granted, problematic in ways, that move towards social justice (Olesen 2007: 421). As such, feminist research is at its best when it reflects the lived experiences of women, when it bridges the gap between mind and body, reason and emotion, thinking and feeling (Jagger 1983, cited by Regan and Brooks 1995: 39). In this regard, Given (2008: 334) suggests opening the dialogical space for research participants to be heard, to share and not to withhold information. Feminist research acknowledges that knowledge and 'truth' are partial, situated, subjective, and relational (Given 2008).

This research employed an ethnographic narrative inquiry from a feminist perspective which implies that we need more than 'imported voices', but critically to "transform and disrupt ideological and/or institutional arrangements ... in a disciplined and caring way" (Carspecken 1996: x). The processes of relational leadership, intended and unintended consequences of observed interaction patterns, relationships and socio-cultural contexts within educational landscapes were investigated. To these ends, the researcher focused on the experiences of a female school principal. The field texts were analysed using constructivist grounded theory (Charmaz 2006), narrative inquiry (Clandinin and Connelly 2000; Clandinin 2007; Clandinin et al. 2007; Slater 2011; Clandinin 2013) and feminist narrative interpretations (Hilfinger Messias and DeJoseph 2004; Landman 2006). Smit (2013) asserts that narrative inquiry, as a relational way of knowing in an educational setting, which was captured ethnographically, is that, as participants tell stories, in whatever forum, researchers reach out to their participants in order to develop relationships by sharing personal experiences related to the topic, trust is created and 'othering' is avoided. Also, "stories that are told depend on the individual's past and present experiences, values, the people the stories are being told to and when and where they are being told" (Klenke 2008: 243). Ethnographic narrative research has an intuitive appeal for the study of female school leadership, although such studies are found infrequently. This is not surprising given the required skills for collecting field texts in an "unaltered, unfiltered form with diligence to record and analyze them" (Klenke 2008: 255).

\section{FINDINGS}

Nomsa ${ }^{1}$ is a successful school principal of a primary school in a rural, disadvantaged school. Her school has over 1000 learners, which means that most classes are overcrowded. In the area many farm schools have closed down and therefor Nomsa's school is growing daily, despite the capping of learner numbers. Many learners come from across the Zimbabwean and Mozambique border. These learners are unable to speak a local African language and English is also foreign to them. This makes class placements quite difficult, and most of the time parents have no documentation either. Almost all the parents of her school are unemployed and rely on government 
grants to support their children. Most families live in squatter camps, and most learners are very poor. It is this reason that Nomsa has started a non-profit organisation (NPO) in order to provide food and daily physical care for the children. This NPO complements the government feeding scheme and as it attends to the physical needs such as washing learners and afternoon homework activities. It happens from time to time that learners come to school sick, but actually they are only hungry. The home situation of many learners is unbearable. Orphans live with their grandparents who rely on old age pension. As the school leader Nomsa is in charge of all the affairs of the school: curriculum, development of people, financial management, learners, infrastructure, as well as parents. She is the link between school and the community. Forging relations with parents, community and local leaders is very important for maintaining a healthy and conducive school climate. Community leaders are powerful people according to Nomsa and relating to them in a positive spirit is to the advantage to her school. During school, Nomsa likes to encourage her staff to deliver on all counts of the requirements of the Department, and teaching and learning. She inspires and motivates her staff. Her relational leadership style has developed over the years, although she sometimes clashes with the authorities. The bureaucratic department in her view does not respond timely to the urgent needs of the school. Also, most teachers who have postgraduate qualifications choose to leave the school and join the district or the Department as administrative officials. Nomsa has decided to stay because in her opinion there is work to be done! Nomsa also relates to her learners as she teaches some classes, especially the reading classes. As a teaching team Nomsa encourages the teachers to devote all their energy to teaching and to their learners. Nomsa is concerned about what happens outside the boundaries of the school. Recently a community uproar forced her to close her school, as learners and teachers' lives were in danger. The local police station, the library and community health clinic were burnt down. Nomsa is extremely perturbed how such angers resort to life-threatening violence and her school community is no longer safe. Furthermore, rape, abuse, and pornography are societal ills that filter into her school. This is accompanied by hunger and acute poverty, a disheartening context for learners. The teachers and Nomsa face these children every day, and one can only speculate how a school leader makes sense of such a working conditions. Nomsa has the gift to give meaning to teachers' and learners' lives. She offers them hope, not only in words and relations but also in tangible endeavours through the NPO. Her relational skills with the community and business in the area have facilitated the development of the NPO in order to meet some of the needs of her learners. Such thoughtfulness and care of the 'other', speaks louder than just words. She puts relational leadership into action.

\section{DISCUSSION}

Relational leadership in the context of female leadership demands an in-depth exploration and understanding as often leadership and gender could be narrowly viewed as a "men-are-autocratic/ women-are-nurturing dichotomy" (Arms 2006: 359). The focus in this paper is not on a dichotomy, instead it traces the qualities that characterise a feminine approach to leadership in contrast to the more traditional approach. In the South African landscape this inquiry seeks a new way of looking at leadership that is anchored in women school leaders. Such leaders bring a spiritual dimension to their work and strive to achieve a balance between the personal and the professional (Arar 2012). Also, one of the women's educational leadership approaches is relational leadership (Grogan and Shakeshaft 2011: 8), which implies "being in relation and sharing power with others". This assumes leading in a caring manner, and seeing the world differently, with vision, with care and with collaboration. In this regard, research by van der Vyver et al. (2014) proposes that care in leadership requires personal development plan for school leaders. This inquiry reveals that relational leadership and associated care is an inherit trend, and does not have to be formally developed. Nomsa conducts her work with a moral code of conduct, she empowers others to achieve and leads by example in and out of school. Her leadership style is evidence that leadership is a social process with a strong relational element (Russell 2003). Responsibilities reach far beyond of what is traditionally known as school. Narratives 'from the ground' together with ethnographic observational field texts redefine leadership, and bring about a new lan- 
guage about leadership, and one that disrupts the male dominated discourse of leadership. Discerning the feminist attributes evident from these field texts speak to the explanatory power of these attributes in relational leadership. Nomsa's leadership experiences reflect feminist attributes of care, collaboration, vision, intuition and courage. Given the findings of this inquiry, leadership in a disadvantaged context requires a redefining not so in terms of tasks, instead as a way of being. Odora Hoppers (2012: 2) offers a helpful explanation in this context: "leadership is a matter of how to be, not how to do. How to do, is the task of a manager. The most effective leaders are a living demonstration of how values and character when combined in action carry the day." As we hear Nomsa's voice in her the data, the researcher envisages that these will empower other teachers and school principals, both male and female to initiate such journeys in their schools appropriating the practice of feminist attributes of leadership to their work as school leaders. Such leadership can enrich school life and create a multiplier effect for the entire school community. No doubt this takes extraordinary courage and resilience to work beyond the boundaries of what commonly considered to be 'school'.

The inquiry draws purposively on a relational epistemology meaning, "all the systems of knowledge are built on relationships" (Wilson 2008 cited by Chilisa 2012). Also, a relational axiology is built on the concept of relational accountability, respectful representation, reciprocal appropriation and rights and regulations during the research process (Chilisa 2012: 22). Theoretically, conceptually, epistemologically and methodologically this inquiry coheres with a feminist, relational and ethnographic narrative research. The topic of relational female leadership fits comfortably in a relational epistemology as the researcher sought ethnographically and narratively the experiences of a female leader in a disadvantaged school setting. Pagano (1990: 135) (cited by Reagan and Brooks 1995: 64) reminds the reader appropriately that "we make ourselves known to ourselves by making ourselves known to each other". Therefore this inquiry invites other female leaders in education to learn from this experience and to build new knowledge, adding to this experience in order to expand the understandings of relational leadership. Given that educational training is dominat- ed by male thinking, managerial positions are mostly understood from that perspective. Relational knowing (Hollingsworth 1992: 386) that draws on feminist attributes may shed light on a different way of leading in schools, particularly in disadvantaged schools. Not many texts speak to relational leadership in disadvantaged schools, specifically on the African continent. Therefore inquiries into the experiences of female leaders from a relational perspective are critical to advance new contextual understandings of leadership. The challenge is to find the language, the words to articulate experiences on the one hand, and on the other to make these contextual understandings accessible and acceptable for the academic community and a male dominated leadership discourse.

\section{CONCLUSION}

Theoretically, leadership is an interactive, dynamic, and mutually interrelational process between leaders and managers, where each participant contributes to the vision and progress toward change. The most effective leaders will be those who are not only visionary, but who are used to working with a diverse population collaboratively rather than in a traditional leadership-follower dynamic. Empirically, an ethnographic narrative inquiry, which is interested in lived and told stories is a form of critical research to facilitate meaning and knowing. This is a compelling reason why knowledge constructed from female leaders' experiences must be disseminated. Perhaps one could ask other female leaders what they would like to have passed on to the young principals following them. The researcher ventures that the feminist attributes could be mentioned. The question remains though, will this relational way of knowing in educational settings be positively received by those in power? The experiences of female educational leaders in South Africa remain largely un-researched and hence, narrative inquiry and ethnography can play a pivotal role into understanding how female leaders negotiate their roles in disadvantaged school communities. Methodical in-depth narrative accounts together with longitudinal ethnographic observations from a feminist perspective do shed light on what happens on the ground in disadvantaged schools led by female principals. Scholarship can learn from these field texts how nuanced, diverse and complex the 
various educational landscapes are and that there is no single answer as to how to lead schools in such contexts. Scholarship learns about educational leadership specifically relational female leadership in disadvantaged communities. Narrative accounts together with detailed ethnographic observations are imperative for student teachers who are studying teacher education and educational management. This inquiry contributes to developing important research in female leadership studies that seeks to draw attention to the limitations of dominant male perspectives.

\section{RECOMMENDATIONS}

Rethinking of leadership as relational leadership emphasises the feminized qualities of connectedness, empathy, emotional sensitivity and vulnerability. Such leadership is a practice of caring for teachers, learners, and community members, enabling others to act, acknowledging and learning from one's mistakes and being emotionally authentic. Leadership has to do with relationships, the role which cannot be overstated. Leadership is inherently a relational, communal process and dependent on context, which is established by the relationships that are valued. Although a person could exert leadership of ideas through persuasive writings or making speeches, most leadership happens in an interactive context between individuals and among group members. Finally, educational leadership is seen as a relational and ethical process of people together attempting to accomplish positive change. Such processes should feature more prominently in leadership training courses in order to raise the mindfulness thereof. Therefore, what is needed is future research that makes visible and practical female school leadership experiences that transpire in various educational landscapes. Nomsa reminds us to restore a caring purpose and relational leadership to such efforts and to help create the kind of schools children deserve.

\section{NOTE}

1. Preudoname.

\section{REFERENCES}

Arar K 2012. Women and leadership: Book review. Educational Management Administration and Leadership, 40(5): 641-646.
Arms E, Collard J, Reynolds C (Eds.) 2006. Leadership, gender and culture in education: Male and female perspectives- Book review. Journal of Educational Change, 7(4): 359-362.

Carspecken PF 1996. Critical Ethnography in Educational Research: A Theoretical and Practical Guide. New York: Routledge.

Cathcart, EB 2014. Relational work: At the core of leadership. Nursing Management, 45(3): 44-46.

Charmaz K 2006. Constructing Grounded Theory: A Practical Guide Through Qualitative Analysis. London: Sage Publications.

Chilisa B 2012. Indigenous Research Methodologies. Los Angeles: Sage Publications.

Clandinin DJ, Connelly FM 2000. Narrative Inquiry: Experience and Story in Qualitative Research. San Francisco: Jossey-Bass.

Clandinin DJ 2006. Narrative inquiry: A methodology for studying lived experience. Research Studies in Music Education, 27(1): 44-54.

Clandinin DJ 2007. Handbook of Narrative Inquiry: Mapping a Methodology. Thousand Oaks: Sage Publications.

Clandinin DJ 2013. Engaging in Narrative Inquiry. Walnut Creek: Left Coast Press, Inc.

Clandinin DJ, Pusher D, Murray Orr A 2007. Navigating sites for narrative inquiry. Journal of Teacher Education, 58(1): 21-35.

Fairhurst GT, Uhl-Bien M 2012. Organizational Discourse Analysis (ODA): Examining leadership as a relational process. The Leadership Quarterly, 23(6): 1043-1062.

Gilligan C 1982. In a Different Voice. Cambridge Massachusetts: Harvard University Press.

Given LM (Ed.) 2008. The Sage Encyclopedia of Qualitative Research Methods. Los Angeles: Sage Publications.

Grogan M, Shakeshaft C 2011. Women and Educational Leadership. San Francisco: Jossey-Bass.

Hilfinger Messias DK, DeJoseph JF 2004. Feminist narrative interpretations: Challenges, tensions and opportunities for nurse researchers. Revista Aquichan, 4(4): 44-49.

Hollingsworth S 1992. Learning to teach through collaborative conversation: A feminist approach, American Educational Research Journal, 29(2): 373404.

Klenke K. 2008. Qualitative Research in the Study of Leadership. Bingley UK: Emerald.

Landman M 2006. Getting quality in qualitative research: A short introduction to feminist methodology and methods. Proceedings of the Nutrition Society, 65(4): 429-433.

Odora Hoppers CA 2012. Ethical African Leadership: We Know Theories, But What is the Task. Unpublished Address to the UNISA Pre-SENEX Meeting.

Olesen VL 2007. Feminist qualitative research and grounded theory: Complexities, criticisms and opportunities. In: A Bryant, K Charmaz (Eds.): The Sage Handbook of Grounded Theory. Los Angeles: Sage Publications, pp. 417-435.

Ospina S, Uhl-Bien M 2012. Exploring the competing bases of legitimacy in contemporary leadership studies. In: M Uhl-Bien, S Ospina (Eds.): Advancing Relational Leadership: A Dialogue Among Perspectives. Charlotte NC: Informational Age, pp. 140. 
Regan HB, Brooks G H 1995. Out of Women's Experience: Creating Relational Leadership. Thousand Oaks: Corwin Press.

Russell M 2003. Leadership and followership as a relational process. Educational Management and Administration, 31(2): 145-157.

Shakeshaft M 2006. Gender and educational management. In: C Skelton, B Francis, I Smulyan (Eds.): The Sage Handbook of Gender and Education. London: Sage Publications, pp. 497-512.

Slater CL 2011. Understanding principal leadership: An international perspective and a narrative approach. Educational Management Administration and Leadership, 39(2): 219-227.

Smit B 2013. Female leadership in a rural school: A feminist perspective. Studies of Tribes and Tribals, 11(1): 89-96.

Uhl-Bien M 2006. Relational leadership theory: Exploring the social processes of leadership and organizing. The Leadership Quarterly, 17(6): 654-676.

Uhl-Bien M 2007. Relational leadership approaches. In: GR Goethals, GJ Sorenson, JM Burns (Eds.): Encyclopedia of Leadership. London: Sage Publications, pp. 1305-1308.

Uhl-Bien M 2011a. Relational leadership and gender: From hierarchy to relationality. In: PH Werhane,
M Painter-Morland (Eds.): Leadership, Gender, and Organization. Dordrecht: Springer, pp. 65-74.

Uhl-Bien M 2011b. Relational leadership theory: Exploring the social processes of leadership and organizing. In: PH Werhane, M Painter-Morland (Eds.): Leadership, Gender, and Organization. Dordrecht: Springer, pp. 75-108.

Van der Vyver, CP, van der Westhuizen PC, Meyer LW 2014. Caring school leadership: A South African study. Educational Management Administration and Leadership, 42(1): 61-74.

Wang H, Sui Y, Luthans F, Wang D, Wu Y 2014. Impact of authentic leadership on performance: Role of followers' positive psychological capital and relational processes. Journal of Organizational Behavior, 35: 5-21.

Werhane PH, Painter-Morland M (Eds.) 2011. Leadership, Gender, and Organization. Dordrecht: Springer.

Young MD, López GR 2005. The nature of inquiry in educational leadership. In: FW English (Ed): The Sage Handbook of Educational Leadership: Advances in Theory and Research. $1^{\text {st }}$ Edition. London: Sage Publication, pp. 337-362. 